\title{
Influence of BrainGym on Mathematical Achievement of Children
}

\author{
Sutoro ${ }^{1}$ \\ ${ }^{1}$ Universitas Cenderawasih (UNCEN), Indonesia \\ Correspondence: Sutoro, Universitas Cenderawasih, Kampus UNCEN Waena, Jl. Camp Wolker, Jayapura, \\ Indonesia. E-mail: sutoro_duin@yahoo.co.id
}

Received: January 16, 2014 Accepted: February 20, 2014 Online Published: February 28, 2014

doi:10.5539/ass.v10n5p114

URL: http://dx.doi.org/10.5539/ass.v10n5p114

\begin{abstract}
The focus of this article is to determine the influence of BrainGym on mathematical achievement of children. The main purpose of this research is to optimize brain activity to better mark the changes in mathematical achievement. The research used a pre test - post test control group design. In the intervention program, the treatment group was given exercises such as training the owl, cross crawl, sit up, and cross-legged kick for as long as 30 minutes. Whereas the control group was not given any exercises. Training was given 3 times per week for as long as 8 weeks. Data analysis conducted found that there is a significant difference in the treatment group between pre test-post test while there is no significant difference in the control group pre test-post test results. Therefore, it can be concluded that brain exercises does influence mathematical achievements.
\end{abstract}

Keywords: BrainGym, treatment group, calculation achievement

\section{Introduction}

Based on the National Education constitution of 1945, all the people of Indonesia is to study without limitation of time or to pursue lifelong education. Nowadays, education is a major priority in Indonesia. However the development of education in Indonesia is still far away compared to developed country. From observations, intelligent students in classrooms, are able to do sports activities especially activities involving complex movements. Students' respond to what they see and listen from their teacher, it will be imitated or it will be done, proves that the work of the nervous system determines the result of muscular activities. According to Sutoro (2004), when the impulse goes through the skeletal muscle, it will cause muscle contraction on that part of the body. This is called physical activity.

Coordination training is some activities combined to create a series of activities which is systematically compiled. In doing this activity, how the move or the movement is need to be thought first. Then, what is the next sequence of movement is. It is clear as Sidharta (1986) said that the motor cortex is part of the cerebrum dominated by pyramid cell, where this cell functions as the transmitter of psychomotor signals along the central nervous system. Research results shows that intelligence improvement is not only determined by total neuron, but also by total synapse. More synapse is formed, the neuron integration is better (Bundah, 2004).

While Dennison and Denisson (2003) said that brain consisted of a few components, generally they are called main brain (cerebral cortex/cerebrum), lateral brain, brain stem, front brain (frontal lobes), and mid brain. Each of them functions differently. Cerebrum and midbrain functions to think abstractly and react to emotional information. Lateral brain functions for psychomotor skill; back brain (occipital) and front brain (frontal lobe) functions is to give attention. According to Maerzyda (2004), frontal lobe is responsible for the ability to do planning, movement, solve problems, and reasoning. Each part of the brain can be optimized by BrainGym training. The movements in BrainGym training are movements usually done by students when they are playing, or doing any sport, while movement orientation in BrainGym is coordination training, which is the combination of eyes movement, hands movement, and body movement.

Research by Anderson (1996) in Sutoro (2004) on mouse trained with the tasks of psychomotor skill in over 30 days, found that there are more synapse in the brain of the trained mouse than in the untrained mouse. Researchers in Baylor College of Medicine at the University of Illinois in Urbana-Campaign, found that when the student is seldom invited to play, his/her brain development is $20 \%$ to $30 \%$ less than the children who constantly play with peers. Research using laboratories animal found that baby mouse grown in a box with all 
toys shows complexity of behavior compared to baby mouse put in a box with no toys. Moreover, they found that the brain of the baby mouse in the box full of toys consisted of $25 \%$ more synapse per neuron (Nash, 1997).

Calculation in arithmatics is the ability to add, subtract, divide, and multiply numbers (Aritmatika, 2002). Arithmatic is still a problem especially for the children in the process of studying. To master calculation needs accuracy, patience, carefulness, and diligence in doing exercises to solve problems correctly and appropriately. The fact shows that the students with high logical thinking will be able to study calculation easily, whereas, the students with low logical thinking will get bored with it.

Coordination training combines eye movement, hand movement, and body movement which can stimulate or optimize nerve activity. All nerve activities is based on the brain, so it is possible that exercising the brain can increase nerve activities and functions so as to think logically and mathematically.

There are many types of movement in Brain Gym to train and stimulate the left and the right brain to perform better. In this research, only three types of movement are used, namely, cross crawl sit up training; the training are as follows; lying down on the floor, knees bent, both hands behind the neck, lift the body, and at the same time swing the knee forward towards the head, and touch left knee with the right elbow, and viceversa . Do this exercise repetitively. The owl training which is as follows; massage one shoulder to relax the neck muscle, than move the head slowly across the middle of the body to the left and then to the right. Breathe out when the head is turning to the left, to the right, facing forward and turn the head down This training is done repetitively and then do the same to the other shoulder. When exhaling, the head is moved further away to the left and right (Dennison \& Dennison, 2003). The cross-legged kick training, is as follows; stand up relax, both hands are beside the body, while jumping, kick the foot in front of the body and touch the left foot with the right hand, and do it repetitively, and do the next movement, that is, kick the foot to the back of the body and touch the right foot with the left hand (Suherman, 2001).

The theory supporting this research is that most people in the world uses about $80 \%-85 \%$ of the left brain and only $15 \%-20 \%$ of the right brain Which one is better, whether the right or the left brain, cannot be explained in detail. It is because each of them has different function, right brain functions in relation to logic, ratio, writing ability, reading ability, and left brain functions in relation to mathematics. Right brain also functions as to socialize, communicate, and as center of intuitive skill.

Ruswaldi Muni and Sri Nilawati (2001) said that to know if someone uses which part of the brain, it can be seen from what he or she does something, by the use of dominating limbs such as either left or right ears, eyes, feet and hands. One who uses the right brain will use the right ear more, the right foot and hand has more power then the left ones. The right brain user is more creative, easy to socialize with, can motivate him/herself and their emotional intelligence is better. Roger Sperry, a psychologist, succeeded in improving certain movements that can affect the brain called BrainGym. At the beginning, this exercises for the brain is used to assist hyper active students, students with attention deficit problems and depression (Kompas, 2001). Khalsa, Kaur and Sifft in Dennison (2003) made a study with 52 students chosen in class of exceptional children. The group using BrainGym shows a serial movements or movement in order, while the control group gets involved in the activity in a disorderly or random fashion in about seven minutes. Visual respond time from all students is tested before and after doing the movement or training is decided. The result shows that students do BrainGym accordingly, their respond time increases, while control group does not.

\section{Method}

This research is an experimental research which needs to fulfill three conditions that are randomization, replication, and control group (Zainudin, 1995). Twenty fifth grade elementary school students were randomly selected for the study out of a population of 60 .

Data is gathered and analysed using t-test with the significant level set at 0.05 (Nasir, 1998). The research design uses Pre test-Post test control group design. It means that the sample is divided into two groups, the control group and treatment group with matching arithmetic ability, to control for sample differences. It means that if there is a difference in calculation achievement between control and experimental group, it is caused only by BrainGym training. To examine the difference, post test was conducted.

Intensity of training for each subject were first decided using $60-70 \%$ of the samples individual maximum ability. After this has been done, the intervention activities begins for the treatment group and was done for 4 weeks. 


\section{Result}

Table 1. Shows the result of the pre test and post test for the control and treatment groups

\begin{tabular}{cccccc}
\hline No & \multicolumn{2}{c}{ Pre test } & No & Treatment & Control \\
\hline 1 & Treatment & Control & & 9.8 & 9.6 \\
2 & 9.8 & 9.6 & 1 & 9 & 7.6 \\
3 & 8 & 8.2 & 2 & 9 & 7.8 \\
4 & 8 & 8 & 3 & 8.6 & 7.4 \\
5 & 7.8 & 8 & 4 & 8.4 & 8 \\
6 & 7.8 & 7.6 & 5 & 7.2 & 8.6 \\
7 & 7.2 & 7.4 & 6 & 7 & 8 \\
8 & 7 & 6.6 & 7 & 6.6 & 1.2 \\
9 & 5.6 & 5.8 & 8 & 5.8 & 7 \\
10 & 5.4 & 5 & 9 & 5.8 & 5 \\
Total & 3.8 & 4.6 & 10 & 77.2 & 70.2 \\
\hline
\end{tabular}

Table 2. Result of t-test

\begin{tabular}{cccccccc}
\hline \multirow{2}{*}{ Group } & \multirow{2}{*}{ N } & \multicolumn{2}{c}{ Mean } & \multicolumn{2}{c}{ Standard deviation } & $\mathrm{t}$ & $\mathrm{p}$ \\
& & Pre test & Post test & Pre test & Post test & & \\
\hline Control & 10 & 7.08 & 7.02 & 1.564 & 2,36 & 0.107 & 0.917 \\
Treatment & 10 & 7.04 & 7.72 & 1.697 & 1.424 & -2.516 & 0.033 \\
\hline
\end{tabular}

Results from t-test analysis shows that for the control group, the differences between pre test and post test is not significant ( $t=0.107, \mathrm{p}>0.05)$. However for the treatment group, there is significant differences between the pre test and the post test scores $(\mathrm{t}=-2.516, \mathrm{p}<0.05)$.

\section{Discussion}

From data gained in both group through pre test, both group had almost the same score, thus it can be assumed that both group started at the same point (Hadi, 1991). After the intervention program in the treatment group through Brain Gym activities, there are significant changes in the post test scores. Thus, it can be concluded that the exercises introduced increases the supply of oxygen to the brain and optimizes the process of thinking (Dennison \& Dennison, 2003), stimulate the nervous system to form new synapse, and effects the thinking process, whereby the brain ability to instruct the muscle to move is more efficient (Suherman, 2002). This is affirmed with the explanation of cortex cerebrum functions as to give response to sensory impulse, coordinated movement, and process of thinking (Guyton, 2002; Thibodeau, 1992).

How does exercising the brain affects calculation achievement? Brain gym training consisting of training the owl, cross crawl sit up, and cross-legged kick training are body movement training which give optimal effect to brain performance in the process of thinking in terms of calculation. It is useful if the student has an IQ of 90, so he/she get brain exercise training; it will optimize his/her brain performance up to the limit point of what he/she really has. Brain exercise training cannot change someone who has lower IQ. But it is to optimize brain performance, although other factors, like nutritious food, can influence the brain performance.

\section{References}

Andi Maerzyda, A. D. (2004). Proses Pematangan Otak, Ayah Bunda Jakarta.

Aritmatika, K. (2002). Mental Aritmatika. Yogyakarta.

Denison, P. E., \& Denison, G. E. (2003). Brain Gym, Edu kinesthetic. Inc, Ventura Californis.

Hadi, S. (1991). Statistik Jilid I. Andi Offset, Yogyakarta. 
Kompas. (2001, July 11). Senam Otak Mudah Dilakukan Banyak Kegunaan. Jakarta.

Madeleine Nash, J. (1997), Otak Anak-Anak. Tira Pustaka, Jakarta.

Majalah, A. B. (2004). Fakta Tumbuh Kembang Otak. Jakarta.

Nazir, M. (1998). Metodologi Penelitian. Ghalia Indonesia, Jakarta.

Suherman, A., \& Mahendra, A. (2001). Menuju Perkembangan Menyeluruh Menyiasati Kurikulum Pendidikan Jasmani di Sekolah Menengah Umum. Jakarta.

Sutoro. (2004). Disertasi Pengaruh Pemberian Stimulus Motorik Terhadap Respons Perubahan Morfologi Sel Pyramid Pada Korteks Motorik Celebrum Mencit. FK UNAIR, Surabaya.

Zainudin, M. (1998). Metodologi Penelitian. Surabaya.

\section{Copyrights}

Copyright for this article is retained by the author(s), with first publication rights granted to the journal.

This is an open-access article distributed under the terms and conditions of the Creative Commons Attribution license (http://creativecommons.org/licenses/by/3.0/). 